Article

\title{
Crystallographic and NMR Investigation of Ergometrine and Methylergometrine, Two Alkaloids from Claviceps Purpurea
}

\author{
Fiorella Meneghetti ${ }^{1}\left(\right.$, Patrizia Ferraboschi $^{2} \oplus$, Paride Grisenti ${ }^{3}$, Shahrzad Reza Elahi ${ }^{2}$, \\ Matteo Mori ${ }^{1}$ (1) and Samuele Ciceri ${ }^{2, *(1)}$ \\ 1 Department of Pharmaceutical Sciences, University of Milan, via L. Mangiagalli, 25, 20133 Milano, Italy; \\ fiorella.meneghetti@unimi.it (F.M.); matteo.mori@unimi.it (M.M.) \\ 2 Department of Medical Biotechnology and Translational Medicine, University of Milan, Via Saldini 50, \\ 20133 Milano, Italy; patrizia.ferraboschi@unimi.it (P.F.); shahrzad.rezaelahi@gmail.com (S.R.E.) \\ 3 Chemical-Pharmaceutical Consulting and IP Management, Viale Giovanni da Cermenate 58, 20141 Milano, \\ Italy; grisenti.paride60@gmail.com \\ * Correspondence: samuele.ciceri@guest.unimi.it; Tel.: +39-02-50316052
}

Received: 11 December 2019; Accepted: 10 January 2020; Published: 14 January 2020

check for updates

\begin{abstract}
Ergometrine and methylergometrine are two alkaloids that are used as maleate salts for the prevention and control of postpartum hemorrhage. Although the two molecules have been known for a long time, few and discordant crystallographic and NMR spectroscopic data are available in the literature. With the aim of providing more conclusive data, we performed a careful NMR study for the complete assignment of the ${ }^{1} \mathrm{H},{ }^{13} \mathrm{C}$, and ${ }^{15} \mathrm{~N}$ NMR signals of ergometrine, methylergometrine, and their maleate salts. This information allowed for a better definition of their conformational equilibria. In addition, the stereochemistry and the intermolecular interactions in the solid state of the two maleate salts were deeply investigated by means of single-crystal X-ray diffraction, showing the capability of these derivatives to act as both hydrogen-bond donors and acceptors, and evidencing a correlation between the number of intermolecular interactions and their different solubility.
\end{abstract}

Keywords: ergot; 9,10-unsaturated ergoline; alkaloids; ${ }^{15} \mathrm{~N}$ NMR; ${ }^{13} \mathrm{C}$ NMR; ${ }^{1} \mathrm{H} \mathrm{NMR}$; X-ray analysis; oxytocic activity

\section{Introduction}

The fungus Claviceps purpurea (commonly known as ergot) is a plant pathogen that produces a family of toxic alkaloids endowed with pharmacological properties [1,2]. These ergot alkaloids are derivatives of the tetracyclic ergoline $\mathbf{1}$ (Figure 1) and can be chemically classified by the nature of the substituent at the 8-position.

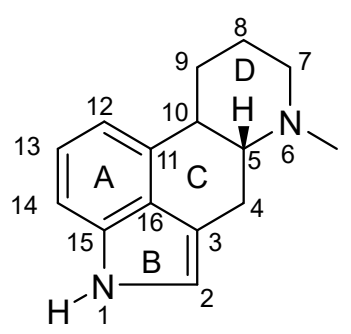

1

Figure 1. Structure of ergoline (1). 
From a therapeutic point of view, the $d$-lysergic acid amides are in a prominent position among the ergot alkaloids. The $d$-lysergic acid 2 carries a carboxyl group at the $8 \beta$ position (cis with respect to the H-5) and a 9-10 double bond (Figure 2). The presence of the double bond is responsible for the easy and spontaneous isomerization of the carboxyl substituent at the C-8 stereocenter, leading to mixtures of $d$-lysergic and $d$-isolysergic acid 3. In the tetracyclic moiety of compounds 2 and 3 , two stereocenters are present, namely at the 5 and 8 positions. The stereocenter at the 5 position presents an $R$ configuration, while the substituent at the 8 position can be either in the $\alpha$-configuration (trans with respect to the $\mathrm{H}-5$ ) or in the $\beta$-configuration (cis with respect to the $\mathrm{H}-5$ ). The $\alpha$-isomer is usually indicated by the prefix iso- or by the ending -inine. The $\beta$-isomers are usually endowed with a significant biological activity.

Among the $d$-lysergic derivatives, the natural amide ergometrine (ergonovine) 4 and the semisynthetic methylergometrine 5 (methylergonovine) (Figure 2) are endowed with uterotonic activity, and for this reason, their maleate salts are administered in the third stage of labor for the prevention of postpartum hemorrhage [3,4].

Although ergometrine 4 was isolated in 1932 [5] and the first synthesis of methylergometrine 5, starting from the lysergic azide, was published in 1943 [6], only a few spectroscopic and crystallographic studies are reported in the literature. In two 2017 Chinese patents [7,8], the ${ }^{1} \mathrm{H}$ NMR data of the ergometrine 4 are reported but not assigned; in 1974 [9], the assigned ${ }^{13} \mathrm{C} \mathrm{NMR}(60 \mathrm{MHz})$ data were reported. In the case of ergometrine maleate, the XRD and the single-crystal X-ray diffraction [10] are reported, and only the ${ }^{1} \mathrm{H}$ NMR $(400 \mathrm{MHz})$ characterization is available [11]. Methylergometrine 5 was analyzed by ${ }^{1} \mathrm{H}$ NMR (values not assigned) in a 2014 WO patent [12]; the corresponding maleate was characterized by XRD, IR, and DSC in a 2015 Chinese patent [13] and by synchrotron powder diffraction data [14]. These incomplete (and sometimes contradictory) NMR and crystallographic analyses prompted us to gather new and more conclusive data for the two amides, 4 and 5 . Considering the easy epimerization of these compounds, we decided to expand our investigations to their maleate salts, 6 and 7, as well. Indeed, ergometrine 4 and methylergometrine 5 are always obtained as mixtures of epimers, while the corresponding maleate salts can be obtained as pure $\beta$-isomers by simple crystallization.

In a continuing effort to fully characterize molecules that exert important therapeutic properties [15-17], a complete NMR $\left({ }^{1} \mathrm{H},{ }^{13} \mathrm{C}\right.$, and $\left.{ }^{15} \mathrm{~N}\right)$ characterization of compounds 4, 5, 6, and 7 was carried out. Moreover, a detailed crystallographic investigation was performed on 6 and 7 in order to explore their conformational features. In addition, we carefully analyzed the hydrogen-bonding interactions of these molecules, as the earlier report did not account for their supramolecular aggregation.

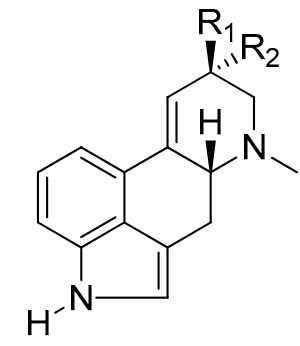

$2 \mathrm{R}_{1}=\mathrm{COOH}, \mathrm{R}_{2}=\mathrm{H}$ $3 \mathrm{R}_{1}=\mathrm{H}, \mathrm{R}_{2}=\mathrm{COOH}$
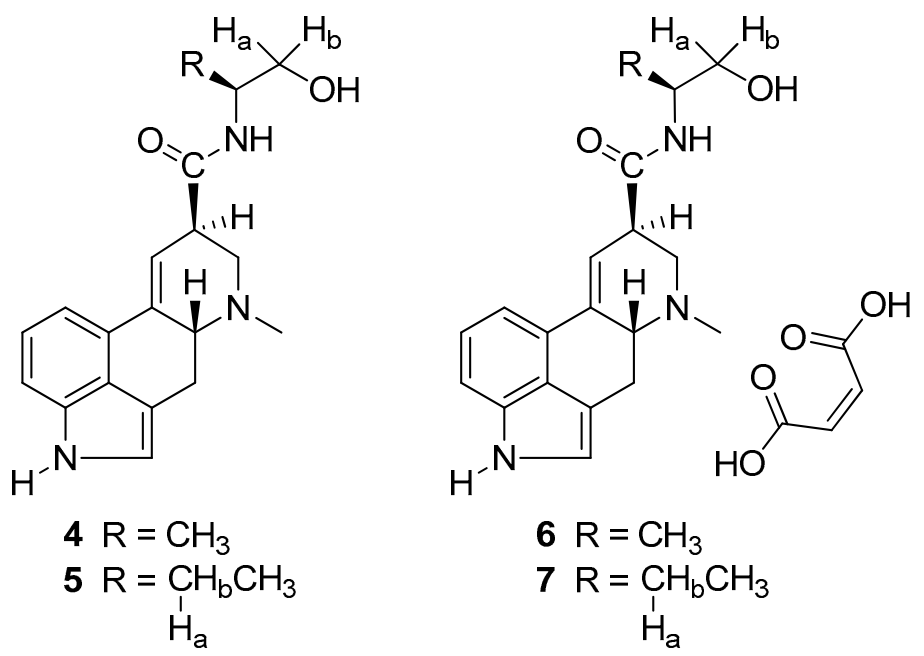

Figure 2. Structures of $d$-lysergic (2), $d$-isolysergic acid (3), ergometrine (4), methylergometrine (5), ergometrine maleate (6), and methylergometrine maleate (7). 


\section{Results and Discussion}

Ergometrine 4 and methylergometrine 5 were obtained by treatment of the corresponding commercially available maleates, 6 and 7, with sodium hydrogen carbonate as described in the Materials and Methods section.

\subsection{NMR Spectroscopy}

The NMR study was carried out on 4 and 5 and on their maleate salts 6 and 7 (the clinically administered derivatives). Compounds 4 and 5 were dissolved in DMSO- $d_{6}$, while compounds 6 and 7 were dissolved in $\mathrm{D}_{2} \mathrm{O}$. Although in both solvents the ${ }^{1} \mathrm{H}$ NMR spectra of 6 and 7 present broadened signals and a slight concentration dependence of chemical shifts, $\mathrm{D}_{2} \mathrm{O}$ was chosen in these cases due to more resolved NMR spectra. ${ }^{1} \mathrm{H},{ }^{13} \mathrm{C}$, and ${ }^{15} \mathrm{~N}$ resonances (Tables $1-3$ ) were unambiguously assigned combining information from $1 \mathrm{D}$ and $2 \mathrm{D}$ NMR (COSY, NOESY, HSQC, ${ }^{1} \mathrm{H}-{ }^{13} \mathrm{C}$ $\mathrm{HMBC}$, and $\left.{ }^{1} \mathrm{H}-{ }^{15} \mathrm{~N} \mathrm{HMBC}\right)$ experiments.

Table 1. ${ }^{1} \mathrm{H}$ NMR chemical shifts (ppm) ${ }^{\mathrm{a}}$ and coupling constants $(\mathrm{Hz})^{\mathrm{b}}$ of compounds 4-7.

\begin{tabular}{|c|c|c|c|c|}
\hline${ }^{1} \mathbf{H}$ & $4\left(\mathrm{DMSO}-d_{6}\right)$ & $5\left(\mathrm{DMSO}-d_{6}\right)$ & $6\left(\mathrm{D}_{2} \mathrm{O}\right)$ & $7\left(\mathrm{D}_{2} \mathrm{O}\right)$ \\
\hline $\mathrm{H}-1$ & 10.69 (brs) & 10.70 (brs) & - & - \\
\hline $\mathrm{H}-2$ & 7.02 (brs) & 7.02 (brs, partially overlapped) & 7.15 (brs) & 7.16 (brs) \\
\hline $\mathrm{H}-4 \alpha$ & 2.44 (overlapped) & 2.45 (overlapped) & $2.89(\mathrm{brt}, J=13.1)$ & $2.91(\mathrm{brt}, J=13.1)$ \\
\hline $\mathrm{H}-4 \beta$ & $3.46(\mathrm{dd}, J=14.9,5.7)$ & $3.46(\mathrm{dd}, J=14.7,5.5)$ & 3.69 (overlapped) & 3.73 (overlapped) \\
\hline $\mathrm{H}-5 \beta$ & $3.00-2.93(\mathrm{~m})$ & $3.00-2.93(\mathrm{~m})$ & $3.92(\mathrm{br})$ & 3.99 (br) \\
\hline $\mathrm{H}-7 \beta$ & 2.50 (overlapped with DMSO) & 2.50 (overlapped with DMSO) & 3.47 (brt, 10.8) & 3.49 (brt, $J=11.7)$ \\
\hline $\mathrm{H}-7 \alpha$ & $3.00(\mathrm{dd}, J=11.0,5.0)$ & $3.02(\mathrm{dd}, J=11.2,5.3)$ & 3.77 (br) & 3.79 (br) \\
\hline $\mathrm{H}-8 \alpha$ & $3.40-3.36(\mathrm{~m}$, overlapped $)$ & 3.47-3.42 (m, overlapped $)$ & 3.83 (br) & 3.89 (overlapped) \\
\hline $\mathrm{H}-9$ & 6.34 (brs) & 6.35 (brs) & 6.46 (brs) & 6.49 (brs) \\
\hline $\mathrm{H}-12$ & 7.04 (overlapped) & $\begin{array}{l}7.03(\text { brdd }, J=8.2,0.8 \\
\text { partially overlapped) }\end{array}$ & $7.22(\mathrm{~d}, J=7.3)$ & $7.23(\mathrm{~d}, J=7.1)$ \\
\hline $\mathrm{H}-13$ & 7.06 (tripletoid $\mathrm{m}$ ) & 7.06 (tripletoid m) & 7.26 (tripletoid $\mathrm{m}$ ) & 7.27 (tripletoid m) \\
\hline $\mathrm{H}-14$ & $7.18(\mathrm{dd}, J=6.9,1.1)$ & $7.18(\mathrm{dd}, J=7.4,0.9)$ & $7.42(\mathrm{~d}, J=7.8)$ & $7.43(\mathrm{~d}, J=7.6)$ \\
\hline $\mathrm{N}-\mathrm{CH}_{3}$ & $2.44(\mathrm{~s})$ & $2.45(\mathrm{~s})$ & $3.11(\mathrm{~s})$ & $3.13(\mathrm{~s})$ \\
\hline $\mathrm{CH}$ & $3.86-3.76(\mathrm{~m})$ & $3.71-3.62(\mathrm{~m})$ & $4.10-4.02(\mathrm{~m})$ & $3.94-3.84(\mathrm{~m})$ \\
\hline $\mathrm{CH}_{3}$ & $1.05(\mathrm{~d}, J=6.6)$ & $0.85(\mathrm{t}, J=7.4)$ & $1.21(\mathrm{~d}, J=6.9)$ & $0.95(\mathrm{t}, J=7.1)$ \\
\hline $\mathrm{CH}_{\mathrm{a}} \mathrm{CH}_{3}$ & - & $1.39-1.26(\mathrm{~m})$ & - & $1.54-1.42(\mathrm{~m})$ \\
\hline $\mathrm{CH}_{\mathrm{b}} \mathrm{CH}_{3}$ & - & $1.66-1.53(\mathrm{~m})$ & - & $1.73-1.62(\mathrm{~m})$ \\
\hline $\mathrm{CH}_{\mathrm{a}} \mathrm{OH}$ & $3.32-3.25(\mathrm{~m})$ & $3.37-3.30(\mathrm{~m})$ & $3.61(\mathrm{dd}, J=11.5,6.6)$ & $3.63(\mathrm{dd}, J=11.7,6.6)$ \\
\hline $\mathrm{CH}_{\mathrm{b}} \mathrm{OH}$ & $3.43-3.36(\mathrm{~m})$ & $3.42-3.38(\mathrm{~m})$ & $3.71(\mathrm{dd}, J=11.7,6.0)$ & $3.73(\mathrm{dd}, J=11.5,4.6)$ \\
\hline $\mathrm{CH}_{2} \mathrm{OH}$ & 4.72 (brs) & $4.68(\mathrm{t}, J=5.7)$ & - & - \\
\hline $\mathrm{CONH}$ & $7.76(\mathrm{~d}, J=7.8)$ & $7.69(\mathrm{~d}, J=8.5)$ & - & - \\
\hline $\begin{array}{l}\mathrm{CH}=\mathrm{CH} \\
\text { maleate }\end{array}$ & - & - & $6.21(\mathrm{~s})$ & $6.23(\mathrm{~s})$ \\
\hline
\end{tabular}

Table 2. ${ }^{13} \mathrm{C}$ NMR chemical shifts (ppm) ${ }^{\text {a }}$ of compounds 4-7.

\begin{tabular}{ccccc}
\hline${ }^{13} \mathbf{C}$ & $\mathbf{4}\left(\mathbf{D M S O}-\boldsymbol{d}_{\mathbf{6}}\right)$ & $\mathbf{5}\left(\mathbf{D M S O}-\boldsymbol{d}_{\mathbf{6}}\right)$ & $\left.\mathbf{6} \mathbf{( D}_{\mathbf{2}} \mathbf{O}\right)$ & $\mathbf{7}\left(\mathbf{D}_{\mathbf{2}} \mathbf{O}\right)$ \\
\hline C-2 & 119.2 & 119.2 & 121.5 & 121.5 \\
C-3 & 109.0 & 109.0 & 106.4 & 106.4 \\
C-4 & 26.8 & 26.8 & 24.8 & 24.7 \\
C-5 & 62.6 & 62.6 & 62.8 & 62.7 \\
C-7 & 55.5 & 55.7 & 54.1 & 54.1 (overlapped) \\
C-8 & 42.8 & 42.9 & 41.4 & 41.5 \\
C-9 & 120.3 & 120.4 & 118.7 & 118.7 \\
C-10 & 135.1 & 135.0 & 132.6 & 132.6 \\
C-11 & 127.4 & 127.5 & 125.1 & 125.2 \\
C-12 & 111.0 & 111.0 & 113.2 & 113.2 \\
C-13 & 122.2 & 122.3 & 124.0 & 124.0 \\
C-14 & 109.7 & 109.7 & 112.2 & 112.2 \\
C-15 & 133.8 & 133.9 & 134.3 & 134.3 \\
C-16 & 125.8 & 125.8 & 125.7 & 125.7 \\
\hline
\end{tabular}


Table 2. Cont.

\begin{tabular}{ccccc}
\hline${ }^{13} \mathbf{C}$ & $\mathbf{4}\left(\mathbf{D M S O}-\boldsymbol{d}_{\mathbf{6}}\right)$ & $\mathbf{5}\left(\mathbf{D M S O}-\boldsymbol{d}_{\mathbf{6}}\right)$ & $\mathbf{6}\left(\mathbf{D}_{\mathbf{2}} \mathbf{O}\right)$ & $\mathbf{7}\left(\mathbf{D}_{\mathbf{2}} \mathbf{O}\right)$ \\
\hline $\mathrm{N}-\mathrm{CH}_{3}$ & 43.4 & 43.4 & 42.1 & 42.0 \\
$\mathrm{CH}$ & 46.5 & 52.1 & 48.3 & 54.2 (overlapped) \\
$\mathrm{CH}_{3}$ & 17.2 & 10.5 & 16.5 & 10.3 \\
$\mathrm{CH}_{2} \mathrm{CH}_{3}$ & - & 23.7 & - & 24.0 \\
$\mathrm{CH}_{2} \mathrm{OH}$ & 64.4 & 63.0 & 65.0 & 63.8 \\
$\mathrm{CH}=\mathrm{CH}$ & - & - & 134.9 & 134.9 \\
maleate & - & - & 171.5 & 171.6 \\
$\mathrm{COOH}$ & 171.2 & 171.7 & 171.8 & 172.4 \\
$\mathrm{CONH}$ & & &
\end{tabular}

${ }^{a}$ Assignments from HSQC and HMBC data.

Table 3. ${ }^{15} \mathrm{~N}$ NMR chemical shifts (ppm) ${ }^{\text {a }}$ of compounds 4-7.

\begin{tabular}{ccccc}
\hline & $\mathbf{4}\left(\mathbf{D M S O}-\boldsymbol{d}_{\mathbf{6}}\right)$ & $\mathbf{5}\left(\mathbf{D M S O}-\boldsymbol{d}_{\mathbf{6}}\right)$ & $\mathbf{6}\left(\mathbf{D}_{\mathbf{2}} \mathbf{O}\right)$ & $\mathbf{7}\left(\mathbf{D}_{\mathbf{2}} \mathbf{O}\right)$ \\
\hline $\mathrm{N}-1$ & $-251.1(128.4)$ & $-251.0(128.5)$ & $-253.3(126.2)$ & $-253.3(126.2)$ \\
N-6 & $-340.3(39.2)$ & $-340.2(39.3)$ & $-332.8(46.7)$ & $-332.7(46.8)$ \\
CONH & $-255.5(124.0)$ & $-258.1(121.4)$ & $-248.3(131.2)$ & $-251.4(128.1)$ \\
\hline
\end{tabular}

a Assignments from ${ }^{1} \mathrm{H}_{-}{ }^{15} \mathrm{~N}$ HMBC data using nitromethane as the external reference $\left(\mathrm{CH}_{3} \mathrm{NO}_{2} \delta=0.00 \mathrm{ppm}\right)$. In parenthesis ${ }^{15} \mathrm{~N}$ chemical shifts referred to ammonia $\left(\delta_{\mathrm{NH} 3}=-379.5 \mathrm{ppm}\right.$ respect to $\left.\mathrm{CH}_{3} \mathrm{NO}_{2}\right)$.

The proton assignments were accomplished using the general knowledge of chemical shift dispersion with the aid of the COSY, HSQC, and NOESY experiments. Starting from the characteristic resonance of $\mathrm{H}-9(6.34,6.35,6.46$, and $6.49 \mathrm{ppm}$ for $4,5,6$, and 7 , respectively), we were able to assign the resonances of all the other protons, especially the resonance of $\mathrm{H}-8$. The interpretation of the ${ }^{1} \mathrm{H}$ NMR spectra of compounds 4 and $\mathbf{5}$ was further facilitated by the resonances of exchangeable protons $\mathrm{H}-1, \mathrm{CH}_{2} \mathrm{OH}$, and $\mathrm{CONH}$.

The NOESY experiments were performed to integrate structural data with stereochemical information. Despite the poorly resolved 2D spectra of NOESY experiments obtained for $\mathbf{6}$ and 7 due to the broad nature of the D-ring proton signals, some information about the stereochemistry and conformation of the D-ring was collected by observing the NOE correlation of the methyl group bound to the nitrogen atom at the 6 position. This methyl group interacts sterically with $\mathrm{H}-5 \beta$, H-7 $\beta, H-7 \alpha$, and H-4 $\beta$, indicating —as previously described by Kidric et al. [18] for 9,10-unsatured ergolines dissolved in solvents such as DMSO and water-that the D-ring was preferentially in its $\mathrm{D}_{1}$ $8 R$ half-chair conformation. The very weak $\mathrm{NOE}$ correlation of $\mathrm{N}-\mathrm{CH}_{3}$ with $\mathrm{H}-8 \alpha$ and $\mathrm{H}-4 \alpha$ could be explained by the existence of a conformational equilibrium in solution between $D_{1} 8 R$ and $D_{2} 8 R$ half-chair conformations (Figure 3). When the D-ring is in its $\mathrm{D}_{2} 8 R$ configuration, the methyl group is in the $\alpha$ position, which results in a feeble NOE effect. The existence of this conformational equilibrium in aqueous solution also explains the broad nature of the $\mathrm{C}$ - and D-ring proton signals.
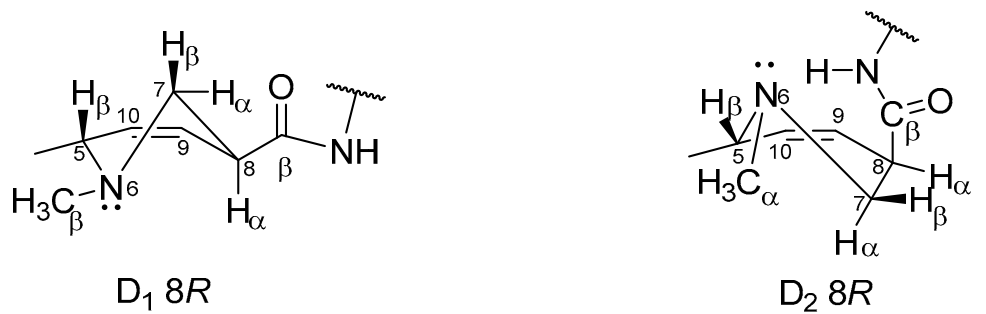

Figure 3. Possible conformations of ergoline D-ring in solution.

The analysis of NOESY spectra of the free bases, 4 and 5 , gave us a clear picture of the spatial interactions of protons at the 4 position with $\mathrm{H}-5 \beta$ and of protons at the 7 position with $\mathrm{H}-8 \alpha$. The NOE 
correlations of $\mathrm{H}-5 \beta$ (3.00-2.93 ppm) with one of the two protons at the 4 position ( $3.46 \mathrm{ppm})$ and of H- $8 \alpha$ (3.40-3.36 ppm) with one of the two protons at the 7 position ( $3.00 \mathrm{ppm}$ for 4 and $3.02 \mathrm{ppm}$ for 5) allowed us to unequivocally identify $\mathrm{H}-4 \beta$ and $\mathrm{H}-7 \alpha$ protons. The absence of spatial interactions between the $\mathrm{H}-8$ and $\mathrm{H}-5$ protons was a clue, but not an absolute proof, of their position on opposite faces of the D-ring. When $\mathrm{N}-\mathrm{CH}_{3}$ (2.44 ppm for $4 ; 2.45 \mathrm{ppm}$ for 5$)$ was irradiated, NOE enhancement was observed for $\mathrm{H}-5 \beta$, suggesting that the analyzed 4 and 5 in DMSO- $\mathrm{d}_{6}$ were in their $\mathrm{D}_{1} 8 R$ half-chair conformation. The $\mathrm{CH}, \mathrm{CH}_{2}$, and $\mathrm{CH}_{3}$ carbon atoms were assigned based on chemical shift analysis and confirmed by the HSQC experiment. In particular, the predicted deshielding of C-5 and C-7 was observed, both near the nitrogen atom in position 6 , further confirming the right ${ }^{1} \mathrm{H}$ NMR assignment of the protons bound to these carbon atoms. In the ${ }^{13} \mathrm{C}$ NMR spectra of compounds 6 and 7 , the broad nature and low intensity of the $\mathrm{C}-4, \mathrm{C}-8, \mathrm{~N}-\mathrm{CH}_{3}, \mathrm{C}-7, \mathrm{C}-5$, and $\mathrm{C}-9$ signals can be explained by the previously reported conformational equilibrium between the $D_{1} 8 R$ and $D_{2} 8 R$ half-chair conformations. The quaternary carbon atoms were unambiguously assigned using the information obtained from ${ }^{1} \mathrm{H}_{-}{ }^{13} \mathrm{C}$ HMBC experiments (Table 4). Following this approach, the ${ }^{13} \mathrm{C}$ resonance assignments of 4 were in accordance with the previously reported ones [9].

Table 4. Long range couplings of hydrogen with quaternary carbon atoms observed in the HMBC spectra of compounds $4-7$.

\begin{tabular}{ccc}
\hline \multirow{2}{*}{ Quaternary Carbon } & \multicolumn{2}{c}{ HMBC $(\mathbf{C} \rightarrow \mathbf{H})$} \\
\cline { 2 - 3 } & $\mathbf{4}$ and $\mathbf{5}\left(\mathbf{D M S O}-\mathbf{d}_{\mathbf{6}}\right)$ & $\mathbf{6}$ and $\left.\mathbf{7} \mathbf{( D}_{\mathbf{2}} \mathbf{O}\right)$ \\
\hline $\mathrm{C}-3$ & $\mathrm{H}-4 \alpha, \mathrm{H}-4 \beta, \mathrm{H}-2, \mathrm{H}-1$ & $\mathrm{H}-4 \alpha, \mathrm{H}-2$ \\
$\mathrm{C}-10$ & $\mathrm{H}-13, \mathrm{H}-12, \mathrm{H}-5, \mathrm{H}-4 \alpha, \mathrm{H}-4 \beta$ & $\mathrm{H}-13, \mathrm{H}-12, \mathrm{H}-4 \alpha$ \\
$\mathrm{C}-11$ & $\mathrm{H}-13, \mathrm{H}-12, \mathrm{H}-9$ & $\mathrm{H}-13, \mathrm{H}-9$ \\
$\mathrm{C}-15$ & $\mathrm{H}-14, \mathrm{H}-13, \mathrm{H}-2, \mathrm{H}-1$ & $\mathrm{H}-13, \mathrm{H}-12, \mathrm{H}-2$ \\
$\mathrm{C}-16$ & $\mathrm{H}-14, \mathrm{H}-12, \mathrm{H}-4 \beta, \mathrm{H}-2, \mathrm{H}-1$ & $\mathrm{H}-14, \mathrm{H}-12, \mathrm{H}-4 \alpha, \mathrm{H}-2$ \\
\hline
\end{tabular}

${ }^{1} \mathrm{H}_{-}{ }^{15} \mathrm{~N}$ HMBC experiments were performed in order to assign the resonances of the three chemically different nitrogen atoms in the examined compounds and allowed us to confirm their hypothesized structure. For compounds 6 and 7, the indole nitrogen N-1 (-253.3 ppm) couples with $\mathrm{H}-2, \mathrm{H}-14$, and $\mathrm{H}-13$, the amidic nitrogen ( $-248.3 \mathrm{ppm}$ for 6; $-251.4 \mathrm{ppm}$ for 7 ) couples with the protons present on the amidic moiety, and curiously but not unexpectedly, N-6 (-332.8 ppm for 6; $-332.7 \mathrm{ppm}$ for 7) couples very weakly only with $\mathrm{H}-4 \alpha$, which gives a well-resolved signal in the ${ }^{1} \mathrm{H}$ NMR spectrum. For compounds 4 and 5 , the indole nitrogen N-1 (-251.1 ppm for $4 ;-251.0 \mathrm{ppm}$ for 5) couples with $\mathrm{H}-1, \mathrm{H}-2, \mathrm{H}-14$, and $\mathrm{H}-13$, the amidic nitrogen ( $-255.5 \mathrm{ppm}$ for $4 ;-258.1 \mathrm{ppm}$ for 5) couples with the protons of the amidic moiety, and N-6 (-340.3 ppm for $4 ;-340.2 \mathrm{ppm}$ for 5$)$ couples with $\mathrm{N}-\mathrm{CH}_{3}, \mathrm{H}-7 \beta$, and $\mathrm{H}-5$.

\subsection{X-ray Analysis}

Since the structure adopted by a given compound upon crystallization could exert a profound effect on the solid-state properties of the system, we decided to perform a crystallographic analysis of derivatives 6 and 7. Their X-ray molecular structures are presented, as ORTEP views [19], in Figure 4. 

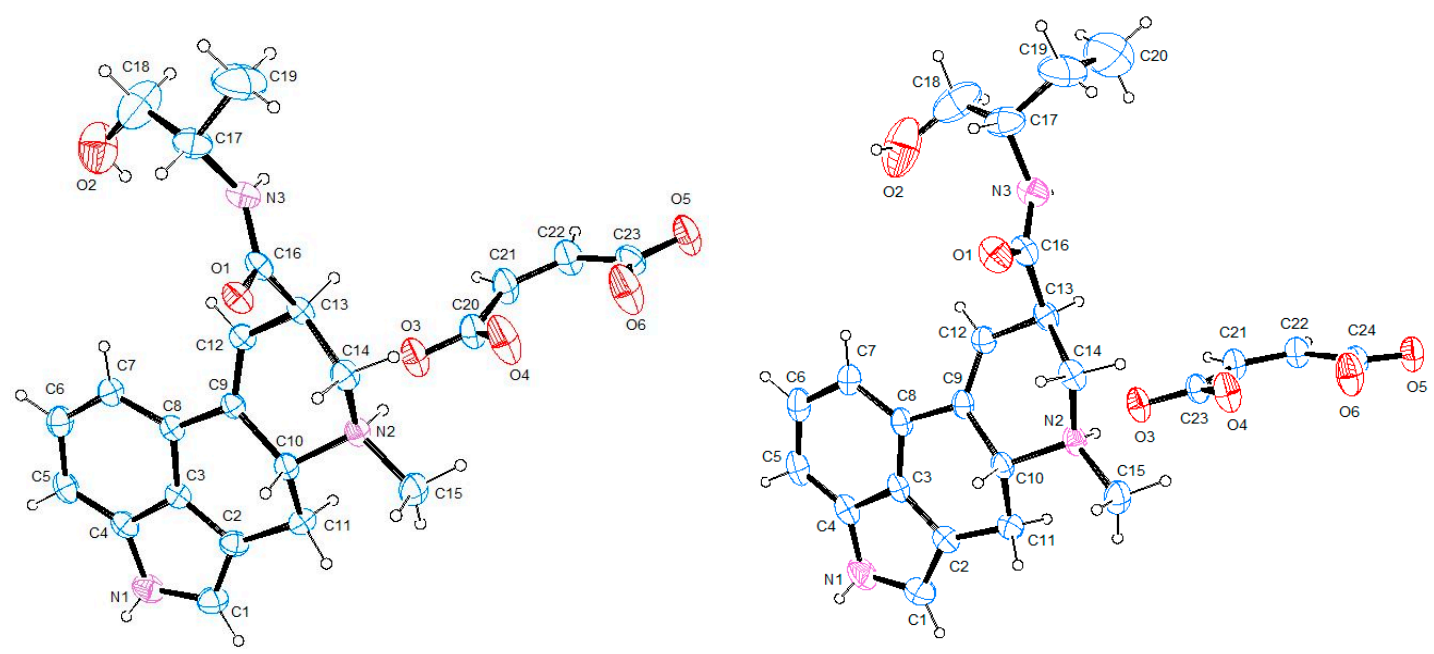

Figure 4. ORTEP drawings [19] of 6 (left) and 7 (right), with the arbitrary atom numbering (ellipsoids are at $40 \%$ probability and $\mathrm{H}$ atoms are represented as spheres of arbitrary radii).

The maleate salt of ergometrine, compound 6 , crystallized in the orthorhombic $\mathrm{P} 2{ }_{1} 2_{1} 2_{1}$ system, as previously reported in the literature [20], while the maleate salt of methylergometrine 7 crystallized in a different space group, namely the monoclinic $\mathrm{P} 2_{1}$ [14].

The dianionic maleate group bridges two neighboring alkaloid molecules, whose conformation is mainly determined by a central rigid core, consisting of an indole plane connected to a six-membered ring and a tetra-hydro-pyridine. Since the absolute configuration of $\mathrm{C} 5$ of the starting material was known, it was possible to determine by X-ray diffraction the relative configuration of $\mathrm{C} 8$ in the two crystal structures. The single crystal diffraction data unambiguously confirmed that the substituent at the 8-position is equatorially oriented (cis with respect to H-5), and with respect to an absolute configuration $\mathrm{R}$ at the 5-position, this relative orientation means the $R$ configuration of $C 8$. The cores of the two molecules are closely related: the ring $C$ of the central skeleton is in a slightly distorted envelope conformation, as indicated by the puckering parameters [21] $\mathrm{Q}_{\mathrm{T}}$ (total puckering amplitude $)=0.3803(1) \AA, \theta$ (torsion angle $)=53.8(1)^{\circ}$ for 6 , and $Q_{T}=0.3630(1) \AA, \theta=51.8(1)^{\circ}$ for 7 , whereas ring $D$ adopts a distorted chair conformation, with puckering coordinates $[21] \mathrm{Q}_{\mathrm{T}}=0.5208$ (1) $\AA, \theta=126.1(1)^{\circ}$ for 6 and $Q_{T}=0.5170(1) \AA, \theta=127.7(1)^{\circ}$ for 7 , which is in agreement with the previously reported structures. The conformation of the tetracyclic system is also conserved in the ergometrinine crystal structure [22], which is the biologically inactive isomer of 4 .

The crystal lattice of both structures is dominated by hydrogen bonds (Figure 5); in 6, in particular, the negatively charged carboxylate groups of the anions are engaged with a hydrogen belonging to the positively charged amino groups of the cations; moreover, bifurcated hydrogen bonds linking O1 with $\mathrm{N} 1$ and $\mathrm{O} 2$ of symmetry-related ergometrine molecules contribute to stabilize the crystals. In addition, $\mathrm{C} \pi-\mathrm{H} \cdot \mathrm{\cdots} \mathrm{O}$ contacts between neighboring anions give rise to the formation of molecular chains along the $a$-axis of the unit cell, further consolidating the crystal packing. In 7, we revealed some differences with respect to the previously reported structure [14]: in particular, the absence of the intermolecular interaction between the amidic oxygen and the $\mathrm{NH}$ of ring $\mathrm{B}$ and the presence of $\mathrm{C} \pi-\mathrm{H} \cdots \mathrm{O}$ contacts between neighboring anions, which give rise to the formation of molecular chains along the $b$-axis of the unit cell. 

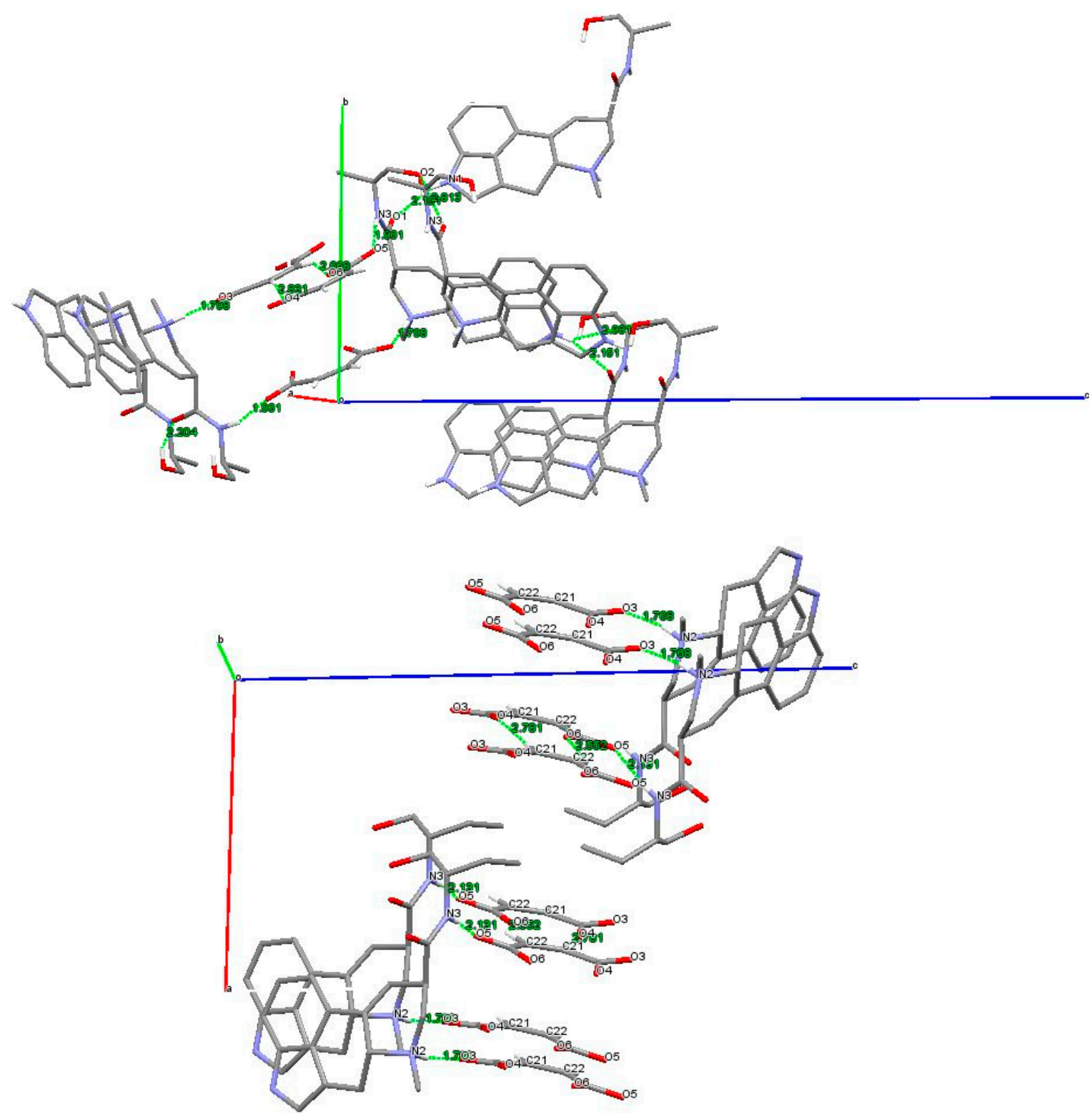

Figure 5. The dashed lines show the intermolecular contacts of 6 (above), viewed about along the $a$-axis, and of 7 (below), viewed about along the $b$-axis (only the hydrogens involved in the interactions are shown).

The hydrogen bond geometry of 6 and 7 , summarized in Table 5, evidenced the capacity of these derivatives to act as both hydrogen-bond donors and acceptors.

Moreover, the crystallographic analysis suggests that the lower solubility of 6 in the crystallization mixture (1:1 acetone/ethanol) is caused by the presence of an extensive system of hydrogen bonding. Therefore, the higher solubility of $\mathbf{7}$ may be correlated to the reduced number of intermolecular interactions found in the solid state, leading to a decreased crystal lattice energy. The less soluble 6 crystallizes in a compact structure as prisms, while the poor-quality crystals of $\mathbf{7}$ (obtained from a 1:1 ethanol/water crystallization mixture) are assembled in transparent platelets, showing a reasonable correlation between the different morphological aspect of the crystals and their solubility. 
Table 5. Hydrogen-bonds geometry of 6 and 7 (arbitrary atom-numbering scheme used in Figure 4).

\begin{tabular}{|c|c|c|c|c|c|c|}
\hline \multirow[b]{2}{*}{ H-Bond } & \multicolumn{3}{|c|}{6} & \multicolumn{3}{|c|}{7} \\
\hline & $\begin{array}{c}\mathbf{H} \cdots \mathbf{A} \\
\text { Distance (A) }\end{array}$ & 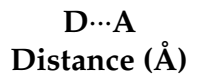 & $\begin{array}{c}\text { D-H } \cdots A \\
\text { Angle }\left({ }^{\circ}\right)\end{array}$ & $\begin{array}{c}\mathbf{H} \cdots \mathbf{A} \\
\text { Distance (Å) }\end{array}$ & 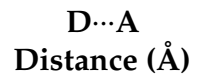 & $\begin{array}{c}\text { D-H } \cdots A \\
\text { Angle }\left({ }^{\circ}\right)\end{array}$ \\
\hline $\mathrm{N} 2-\mathrm{H} \cdots \mathrm{O} 3$ & $1.8(1)$ & $2.7(1)$ & $176(1)$ & $1.8(1)$ & $3.2(1)$ & $168(1)$ \\
\hline $\mathrm{N} 1-\mathrm{H} \cdots \mathrm{O} 2^{\mathrm{I}}$ & $2.9(1)$ & $3.5(1)$ & $140(1)$ & - & & - \\
\hline $\mathrm{C} 22-\mathrm{H} \cdots \mathrm{O} 6^{\mathrm{II}}$ & $2.7(1)$ & $3.3(1)$ & $134(1)$ & $2.7(1) \mathrm{V}$ & $3.3(1)$ & $130(1)$ \\
\hline $\mathrm{C} 21-\mathrm{H} \cdots \mathrm{O} 4{ }^{\mathrm{II}}$ & $2.8(1)$ & $3.7(1)$ & 171(1) & - & & - \\
\hline $\mathrm{C} 21-\mathrm{H} \cdots \mathrm{O}^{\mathrm{II}}$ & $2.7(1)$ & $3.4(1)$ & $132(1)$ & $2.6(1) \mathrm{V}$ & $3.3(1)$ & $133(1)$ \\
\hline $\mathrm{O} 2-\mathrm{H} \cdots \mathrm{O} 1 \mathrm{II}$ & $2.2(1)$ & $2.8(1)$ & $131(1)$ & - & & - \\
\hline $\mathrm{N} 1-\mathrm{H} \cdots \mathrm{O} 1{ }^{\mathrm{III}}$ & $2.1(1)$ & $2.8(1)$ & $155(1)$ & - & & - \\
\hline $\mathrm{N} 3-\mathrm{H} \cdots \mathrm{O} 5{ }^{\mathrm{IV}}$ & $2.1(1)$ & $2.9(1)$ & $163(1)$ & 2.1(1) VI & 2.(1) & $172(1)$ \\
\hline
\end{tabular}

Equivalent positions: ${ }^{\mathrm{I}}-\mathrm{x}, \mathrm{y}-1 / 2,1 / 2-\mathrm{z} ;{ }^{\mathrm{II}} \mathrm{x}-1, \mathrm{y}, \mathrm{z} ;{ }^{\mathrm{III}} 1-\mathrm{x}, \mathrm{y}-1 / 2,1 / 2-\mathrm{z} ;{ }^{\text {IV }} \mathrm{x}-1 / 2,1 / 2-\mathrm{y},-\mathrm{z} ;{ }^{\mathrm{V}} \mathrm{x}, \mathrm{y}+1, \mathrm{z}$; $\mathrm{VI}-\mathrm{x}, \mathrm{y}+1 / 2,1-\mathrm{z}$.

\section{Materials and Methods}

\subsection{Chemistry}

Ergometrine maleate and methylergometrine maleate, all reagents and solvents were purchased from Sigma-Aldrich (Merck, Kenilworth, NJ, USA).

\subsubsection{Ergometrine 4 from the Corresponding Maleate 6}

To a suspension of commercial ergometrine maleate $(50 \mathrm{mg}, 0.11 \mathrm{mmol})$ in ethyl acetate $(10 \mathrm{~mL})$, a saturated aqueous sodium bicarbonate solution $(10 \mathrm{~mL})$ was added. After stirring at room temperature in the dark for $30 \mathrm{~min}$, the layers were separated. The aqueous phase was extracted with ethyl acetate $(2 \times 10 \mathrm{~mL})$. The collected organic phases were dried over sodium sulfate and filtered. After solvent removal under reduced pressure, a white solid was obtained (35 mg, $0.11 \mathrm{mmol}, 96 \%$ ).

$$
[\alpha]_{\mathrm{D}}^{20}=-17.9^{\circ}(\mathrm{c}=1 \text {; pyridine }) \text { lit. }[6]-16^{\circ}
$$

\subsubsection{Methylergometrine 5 from the Corresponding Maleate 7}

Methylergometrine 5 was obtained following the previously described procedure for ergometrine 4 , starting from commercial methylergometrine maleate $(50 \mathrm{mg}, 0.11 \mathrm{mmol})$. A white solid was obtained (34 mg, $0.10 \mathrm{mmol}, 91 \%$ ).

$$
[\alpha]_{\mathrm{D}}^{20}=-49.8^{\circ}(\mathrm{c}=0.4 ; \text { pyridine }) \text { lit. }[6]-45^{\circ}
$$

\subsection{NMR Spectroscopy}

NMR spectra were recorded on a Bruker AVANCE 500 spectrometer (Bruker, Billerica, MA, USA) equipped with a $5 \mathrm{~mm}$ broadband inverse (BBI) detection probe with field $z$-gradient operating at $500.13,125.76$, and $50.69 \mathrm{MHz}$ for ${ }^{1} \mathrm{H},{ }^{13} \mathrm{C}$, and ${ }^{15} \mathrm{~N}$ respectively. NMR spectra were recorded at $300 \mathrm{~K}$ for compounds 4 and 5 in DMSO- $d_{6}$ (isotopic enrichment 99.9 atom \% D), for their maleate salts, 6 and 7, in $\mathrm{D}_{2} \mathrm{O}$ (isotopic enrichment 99.9 atom \% D) solution. The data were collected and processed by XWIN-NMR software (version 3.5, Bruker, Billerica, MA, USA) running on a PC with Microsoft Windows 7. The samples $(10 \mathrm{mg})$ were dissolved in the appropriate solvent $(0.75 \mathrm{~mL})$ in a $5 \mathrm{~mm}$ NMR tube. The acquisition parameters for 1D were as follows: ${ }^{1} \mathrm{H}$ spectral width of $5000 \mathrm{~Hz}$ and $32 \mathrm{~K}$ data points providing a digital resolution of ca. $0.305 \mathrm{~Hz}$ per point, relaxation delay $10 \mathrm{~s} ;{ }^{13} \mathrm{C}$ spectral width of $29,412 \mathrm{~Hz}$, and $64 \mathrm{~K}$ data points providing a digital resolution of ca. $0.898 \mathrm{~Hz}$ per point, relaxation delay $2 \mathrm{~s}$. The experimental error in the measured ${ }^{1} \mathrm{H}-{ }^{1} \mathrm{H}$ coupling constants was $\pm 0.5 \mathrm{~Hz}$. Chemical shifts $(\delta)$ of the ${ }^{1} \mathrm{H}$ NMR and ${ }^{13} \mathrm{C}$ NMR spectra are reported in ppm using the central peak of DMSO- $d_{6}$ signals $\left(2.50 \mathrm{ppm}\right.$ for ${ }^{1} \mathrm{H} ; 39.52 \mathrm{ppm} \mathrm{for}{ }^{13} \mathrm{C}$ ) for compounds 4 and 5 and using methanol as 
external reference in the spectra recorded in $\mathrm{D}_{2} \mathrm{O}$ (signals of $\mathrm{CH}_{3} \mathrm{OH}$ in $\mathrm{D}_{2} \mathrm{O}$ : 3.34 ppm for ${ }^{1} \mathrm{H} ; 49.50$ ppm for ${ }^{13} \mathrm{C}$ ). Methylergometrine maleate $\mathrm{D}_{2} \mathrm{O}$ solution showed a $\mathrm{pH}$ of 4.5 , while ergometrine maleate $\mathrm{D}_{2} \mathrm{O}$ solution showed a $\mathrm{pH}$ of 4.2. The splitting pattern abbreviations are as follows: s, singlet; $\mathrm{d}$, doublet; t, triplet; q, quartet; m, multiplet; and br, broad signal. For two-dimensional experiments, standard Bruker microprograms using gradient selection (gs) were applied. Gs-COSY-45 and phase sensitive gs-NOESY experiments were acquired with $512 \mathrm{t} 1$ increments; $2048 \mathrm{t} 2$ points; and a spectral width of $11.0 \mathrm{ppm}$. The gs-NOESY experiments were performed with a mixing time of $0.800 \mathrm{~s}$ on samples degassed under a flush of argon in a screwcap sample tube. There were not significant differences in the results obtained at different mixing times (0.5-1.5 s). The acquisition data for gs-HSQC and gs-HMBC experiments were acquired with $512 \mathrm{t} 1$ increments, $2048 \mathrm{t} 2$ points, and a spectral width of $11.0 \mathrm{ppm}$ for ${ }^{1} \mathrm{H}$ and $200 \mathrm{ppm}$ for ${ }^{13} \mathrm{C}$. Delay values were optimized for ${ }^{1} J_{\mathrm{C}, \mathrm{H}} 140 \mathrm{~Hz}$ and ${ }^{\mathrm{n}} J_{\mathrm{C}, \mathrm{H}} 8.0 \mathrm{~Hz}$. For ${ }^{1} \mathrm{H}-{ }^{15} \mathrm{~N}$ HMBC experiments, nitromethane was used as the external reference, referencing the resonance of its ${ }^{15} \mathrm{~N}$ at $0.00 \mathrm{ppm}$. Samples concentration: $10 \mathrm{mg} / 0.75 \mathrm{~mL}$ corresponding to 41, 39, 30, and $29 \mathrm{mM}$ for 4, 5, 6, and 7, respectively. The acquisitions were performed setting an acquisition time of $0.5 \mathrm{~s}$, a delay between scans of $10 \mathrm{~s}, \mathrm{a}^{1} J_{\mathrm{N}, \mathrm{H}}$ value of $90.0 \mathrm{~Hz}$, and a ${ }^{\mathrm{n}} J_{\mathrm{N}, \mathrm{H}}$ value of $1.9 \mathrm{~Hz}$. This last parameter was set after several attempts between 1 and $10 \mathrm{~Hz}$. Total ${ }^{1} \mathrm{H}^{15}{ }^{15} \mathrm{HMBC}$ experimental time: $64 \mathrm{~h}$.

The NMR spectra are available in the Supplementary Materials section.

\subsection{X-ray Crystallography}

Crystals of 6 were obtained as pale-yellow prisms from a 1:1 acetone/ethanol solution at room temperature. Poor-quality crystals of 7 were obtained, after many attempts, as colorless elongated platelets from a 1:1 ethanol/water solution at room temperature. All experiments were carried out in the dark to avoid degradation.

Diffraction data for the crystals of 6 and 7 were collected with a Bruker-AXS CCD-based three-circle diffractometer, working at ambient temperature with graphite-monochromatized Mo-K $\alpha$ X-ray radiation $(\lambda=0.7107 \AA)$.

$X$-ray diffraction data in the $\theta$ range $2-25^{\circ}$ were collected acquiring three sets of 600 bidimensional CCD frames with the following operative conditions: omega rotation axis, scan width $0.3^{\circ}$, acquisition time $40 \mathrm{~s}$, sample-to-detector distance $60 \mathrm{~mm}$, and phi angle fixed at three different values $\left(0^{\circ}, 120^{\circ}\right.$, $240^{\circ}$ ) for the three different sets.

Omega-rotation frames were processed with the SAINT software [23] for data reduction (including intensity integration, background, Lorentz, and polarization corrections) and for the determination of accurate unit-cell dimensions, which were obtained by least-squares refinement of the positions of 2023 independent reflections with $\mathrm{I}>10 \sigma(\mathrm{I})$ in the $\theta$ range $2-19^{\circ}$. Absorption effects were empirically evaluated by the SADABS software [24], and absorption correction was applied to the data (0.87 and 0.99 min and max transmission factor). The structures were solved by direct methods (SIR-14) [25] and completed by iterative cycles of full-matrix least squares refinement on $\mathrm{F}_{0}{ }^{2}$ and DF synthesis using the WingX.v2014.1 [26] program. The hydrogen atoms bonded to carbon were included at geometrically calculated positions and refined using a riding model. Uiso(H) is defined as 1.2 Ueq of the parent carbon atoms for the phenyl and methylene residues and $1.5 \mathrm{Ueq}$ of the parent carbon atoms for the methyl group. Crystallographic data has been deposited with the Cambridge Crystallographic Data Centre under CCDC deposition numbers 1970319 (6) and 1970320 (7). Copies of this information may be obtained free of charge from the Director, CCDC, 12 Union Road, Cambridge CB2 1EY, UK (fax: +44-1223-336033; e-mail: deposit@ccdc.cam.ac.uk or www:http://www.ccdc.cam.ac.uk).

Crystal data for 6: $\mathrm{C}_{23} \mathrm{H}_{27} \mathrm{~N}_{3} \mathrm{O}_{6}, M_{\mathrm{r}}=441.47 \mathrm{~g} / \mathrm{mol}$, Orthorhombic, Space group $P 2{ }_{1} 2{ }_{1} 2_{1}$, $a=5.7139(7) \AA, b=12.3104(1) \AA, c=33.2683(4) \AA, V=2340(1) \AA^{3}, Z=4, D_{\text {calc }}=1.253 \mathrm{Mg} / \mathrm{m}^{3}, \mathrm{~F}(000)=936$, $R=0.057$ (reflections collected/unique $=4113 / 2921), w R 2=0.146, T=294(2) \mathrm{K}$, and GOF $=1.026$. The reflections were collected in the range $1.22^{\circ} \leq \theta \leq 25.05^{\circ}$ (limiting indices $=-6 \leq \mathrm{h} \leq 6,-14 \leq \mathrm{k} \leq 14$, 
$-39 \leq 1 \leq 39)$ employing a $0.30 \times 0.20 \times 0.07 \mathrm{~mm}$ crystal. The residual positive and negative electron densities in the final map were 0.303 and $-0.176 \AA^{-3}$.

Crystal data for 7: $\mathrm{C}_{24} \mathrm{H}_{29} \mathrm{~N}_{3} \mathrm{O}_{6}, M_{\mathrm{r}}=455.5 \mathrm{~g} / \mathrm{mol}$, Monoclinic, Space group $P 2{ }_{1}, a=10.844$ (1) $\AA$, $b=5.702(6) \AA, c=21.029(2) \AA, \beta=91.469(2) Z=2, \mathrm{~V}=1299.2(4) \AA^{3}, D_{\text {calc }}=1.164 \mathrm{Mg} / \mathrm{m}^{3}, \mathrm{~F}(000)=484$, $R=0.056$ (reflections collected/unique $=4577 / 3576), w R 2=0.1607, T=294(2) \mathrm{K}$, and GOF $=1.052$. The reflections were collected in the range $0.969^{\circ} \leq \theta \leq 25.04^{\circ}$ (limiting indices $=-12 \leq \mathrm{h} \leq 12,-6 \leq \mathrm{k} \leq 6$, $-25 \leq 1 \leq 25$ ) employing a $0.30 \times 0.08 \times 0.03 \mathrm{~mm}$ crystal. The residual positive and negative electron densities in the final map were 0.486 and $-0.296 \AA^{-3}$.

\subsection{Optical Rotatory Power}

The values of optical rotations were registered on a polarimeter (mod. 241, PerkinElmer, Waltham, MA, USA) in a $1 \mathrm{dm}$ path length cell at $20^{\circ} \mathrm{C}$, setting the wavelength at $589 \mathrm{~nm}$.

\section{Conclusions}

Although ergometrine and methylergometrine have been known for over 70 years and they have been used as antihemorrhagic agents for a long time, few and sometimes contradictory NMR and crystallographic data are available in the literature. In this work, we provide the complete assignment of ${ }^{1} \mathrm{H},{ }^{13} \mathrm{C}$, and ${ }^{15} \mathrm{~N}$ NMR signals of ergometrine, methylergometrine, and their maleate salts together with a solid-state analysis of ergometrine maleate and methylergometrine maleate. The new and more accurate X-ray and NMR data will contribute to widen the available information about conformational equilibria and hydrogen-bonding interactions, which could prove useful for the study of other ergot alkaloids.

Supplementary Materials: The following are available online, The NMR spectra $\left({ }^{1} \mathrm{H},{ }^{13} \mathrm{C}, \mathrm{COSY}, \mathrm{HSQC}\right.$, ${ }^{1} \mathrm{H}^{-13} \mathrm{C}$ HMBC, ${ }^{1} \mathrm{H}_{-}^{-15} \mathrm{~N}$ HMBC and NOESY) of compounds 4-7 are available online.

Author Contributions: Conceptualization of the work: P.F. and P.G.; synthesis: S.R.E.; crystallographic analysis: F.M. and M.M.; NMR analysis: S.C.; writing-original draft preparation, review and editing: F.M., P.F. and S.C.; supervision: P.F. All authors have read and agreed to the published version of the manuscript.

Funding: This research received no external funding.

Conflicts of Interest: The authors declare no conflict of interest.

\section{References}

1. De Groot, A.N.; van Dongen, P.W.; Vree, T.B.; Hekster, Y.A.; van Roosmalen, J. Ergot alkaloids. Current status and review of clinical pharmacology and therapeutic use compared with other oxytocics in obstetrics and gynaecology. Drugs 1998, 56, 523-535. [PubMed]

2. Rutschmann, J.; Stadler, P.A. Chemical Background. In Ergot Alkaloids and Related Compounds; Berde, B.S., Ed.; Springer: Berlin, Germany, 1978; pp. 29-85.

3. Moir, J.C. Ergot: From "St. Anthony's Fire" to the isolation of its active principle, ergometrine (ergonovine). Am. J. Obstet. Gynecol. 1974, 120, 291-296. [CrossRef]

4. Rall, T.W. Drug affecting uterine motility: Oxitocyn, prostaglandins, ergot alkaloids and other drugs. Tocolytic agents. In Goodman E Gilman's: The Pharmacological Basis of Therapeutics, 8th ed.; MacMillan: New York, NY, USA, 1990; pp. 933-953.

5. Dudley, H.W.; Moir, J.C. THE new active principle of ergot. Science 1935, 81, 559-560. [CrossRef] [PubMed]

6. Stoll, A.; Hofmann, A. Ergot alkaloids. VI. Partial synthesis of ergobasine type alkaloids. Helv. Chim. Acta 1943, 26, 944-965. [CrossRef]

7. Liu, G.; Huang, H.; Wu, X.; Chen, D.; Ren, J.; Li, Y.; Su, Z. Preparation of Ergometrine. Patent CN106866657A, 25 April 2017.

8. Liu, G.; Wu, X.; Huang, H.; Li, Y.; Su, Z. Preparation of Racemic Lysergic Acid by utilizing fermn. Waste and Its Application for Preparation of Ergometrine. Patent CN106397429A, 15 February 2017.

9. Bach, N.J.; E Boaz, H.; Kornfeld, E.C.; Chang, C.J.; Floss, H.G.; Hagaman, E.W.; Wenkert, E. Nuclear magnetic resonance spectral analysis of the ergot alkaloids. J. Org. Chem. 1974, 39, 1272-1276. [CrossRef] [PubMed] 
10. Cejka, J.; Hušák, M.; Kratochvíl, B.; Jegorov, A.; Cvak, L. Crystal Structures of Ergot Alkaloid Derivatives. Ergometrine Maleate and Methylergometrine Maleate. Collect. Czechoslov. Chem. Commun. 1996, 61, 1396-1404. [CrossRef]

11. Casy, A.F. Rapid identification of ergot derivatives by 1 H-NMR spectroscopy. J. Pharm. Biomed. Anal. 1994, 12, 27-40. [CrossRef]

12. Wu, L.; Zhang, J. Novel Methysergide Derivatives. Patent WO2014100354A1, 26 June 2014.

13. He, Q.; Zhang, M.; Wu, J.; Zuo, W.; Sun, S.; Jia, C.; Xia, T. Methylergometrine Maleate Compound and Preparation Method. Patent CN105085514A, 25 November 2015.

14. Rohlíček, J.; Hušák, M.; Kratochvíl, B.; Jegorov, A. Methyl-ergometrine maleate from synchrotron powder diffraction data. Acta Crystallogr. Sect. E Struct. Rep. Online 2009, 65, o3252-03253. [CrossRef] [PubMed]

15. Ferraboschi, P.; Ciuffreda, P.; Ciceri, S.; Grisenti, P.; Castellano, C.; Meneghetti, F. Crystallographic and spectroscopic study on a known orally active progestin. Steroids 2015, 104, 137-144. [CrossRef] [PubMed]

16. Ferraboschi, P.; Colombo, D.; Legnani, L.; Toma, L.; Grisenti, P.; Vistoli, G.; Meneghetti, F. Crystallographic, Spectroscopic, and Theoretical Investigation of the Efficiently Separated 21R and 21S-Diastereoisomers of Argatroban. Chirality 2013, 25, 871-882. [CrossRef] [PubMed]

17. Ferraboschi, P.; Sala, M.C.; Stradi, R.; Ragonesi, L.; Gagliardi, C.; Lanzarotti, P.; Ragg, E.M.; Mori, M.; Meneghetti, F. Full spectroscopic characterization of two crystal pseudopolymorphic forms of the antiandrogen cortexolone 17 alpha-propionate for topic application. Steroids 2017, 128, 95-104. [CrossRef] [PubMed]

18. Kidric, J.; Kocjan, D.; Hadzi, D. Conformational-Analysis of the D-Ring of Lysergic-Acid Amides and Its Bioactive Conformation. Croat. Chem. Acta 1985, 58, 389-397.

19. Farrugia, L.J. ORTEP -3 for Windows-A version of ORTEP -III with a Graphical User Interface (GUI). J. Appl. Crystallogr. 1997, 30, 565. [CrossRef]

20. Husak, M.; Kratochvíl, B.; Jegorov, A. Crystal structure of ergometrine ethyl acetate solvate (2:1), (C19H23N3O2)2(C4H8O2). Z. Krist. New Cryst. Struct 1998, 213, 195-196.

21. Cremer, D.; Pople, J.A. General definition of ring puckering coordinates. J. Am. Chem. Soc. 1975, 97, 1354-1358. [CrossRef]

22. Merkel, S.; Koppen, R.; Koch, M.; Emmerling, F.; Nehls, I. Ergometrinine. Acta Crystallogr. Sect. E Struct. Rep. Online 2010, 66, o2275. [CrossRef] [PubMed]

23. Bruker. SAINT Software Reference Manual, version 6; Bruker AXS Inc.: Madison, WI, USA, 2003.

24. Krause, L.; Herbst-Irmer, R.; Sheldrick, G.M.; Stalke, D. Comparison of silver and molybdenum microfocus X-ray sources for single-crystal structure determination. J. Appl. Crystallogr. 2015, 48, 3-10. [CrossRef] [PubMed]

25. Altomare, A.; Burla, M.C.; Camalli, M.; Cascarano, G.L.; Giacovazzo, C.; Guagliardi, A.; Moliterni, A.G.G.; Polidori, G.; Spagna, R. SIR97: A new tool for crystal structure determination and refinement. J. Appl. Crystallogr. 1999, 32, 115-119. [CrossRef]

26. Sheldrick, G.M. Crystal structure refinement with SHELXL. Acta Crystallogr. Sect. C Struct. Chem. 2015, 71, 3-8. [CrossRef] [PubMed]

Sample Availability: Samples of the compounds 4-7 are available from the authors.

(C) 2020 by the authors. Licensee MDPI, Basel, Switzerland. This article is an open access article distributed under the terms and conditions of the Creative Commons Attribution (CC BY) license (http://creativecommons.org/licenses/by/4.0/). 